\title{
New distribution records of the gall crab Opecarcinus cathyae van der Meij, 2014 (Decapoda: Brachyura: Cryptochiridae) from the Red Sea, Maldives and Japan
}

\author{
Sancia E. T. van der Meij ${ }^{1,2}$ - Francesca Benzoni ${ }^{3,4}$ - Michael L. Berumen ${ }^{5}$. \\ Tohru Naruse ${ }^{6}$
}

Received: 1 September 2016/Revised: 23 October 2016 / Accepted: 24 October 2016 / Published online: 12 November 2016

(C) The Author(s) 2016. This article is published with open access at Springerlink.com

\begin{abstract}
The gall crab Opecarcinus cathyae van der Meij, 2014 has been reported from various localities in Indonesia and Malaysia. Recent surveys in the Red Sea, Maldives and Japan yielded additional specimens of $O$. cathyae, considerably expanding the known distribution range of this species to the east and west. The identity of $O$. cathyae was confirmed based on COI sequence data, revealing identical haplotypes for the Red Sea, Maldivian and Japanese material and three haplotypes in the Indonesian material. Opecarcinus cathyae has one of the widest known recorded distribution ranges for all gall crab species.
\end{abstract}

Communicated by S. De Grave

Sancia E. T. van der Meij

sancia.vandermeij@oum.ox.ac.uk

1 Oxford University Museum of Natural History, University of Oxford, Parks Road, Oxford OX1 3PW, UK

2 Naturalis Biodiversity Center, Darwinweg 2, 2333 CR Leiden, The Netherlands

3 Department of Biotechnologies and Biosciences, University of Milano - Bicocca, Piazza della Scienza 2, 20126 Milan, Italy

4 UMR ENTROPIE (IRD, Université de La Réunion, CNRS), Laboratoire d'excellence-CORAIL, centre IRD de Nouméa, 101 Promenade Roger Laroque, BP A5, 98848 Noumea Cedex, New Caledonia

5 Red Sea Research Center, Division of Biological and Environmental Science and Engineering, King Abdullah University of Science and Technology, Thuwal 23955-6900, Saudi Arabia

6 Tropical Biosphere Research Center, Iriomote Station, University of the Ryukyus, 870 Uehara, Taketomi, Okinawa 907-1541, Japan
Keywords Coral reef $\cdot$ Host specificity $\cdot$ Indo-Pacific

\section{Introduction}

The gall crab Opecarcinus cathyae van der Meij, 2014 was originally described from Indonesia and Malaysia, where it was found to inhabit the stony corals Pavona clavus (Dana, 1846) and P. bipartita Nemenzo, 1980. A possible distribution record of $O$. cathyae from Fiji was included in the original description, based on the presence of a dwelling in the holotype of P. clavus (van der Meij 2014). Here, we present new records of $O$. cathyae from the Saudi Arabian part of the Red Sea, the Maldives and the Ogasawara Islands in Japan.

Many coral reefs remain understudied for Cryptochiridae, and gall crab records are few and far between for the Red Sea and the Maldives (respectively, 5 and 6 recorded species; reviewed in van der Meij 2015a; van der Meij et al. 2015). Based on the high coral diversity in the Red Sea and the Maldives, many more gall crab species are expected to occur on these reefs. The gall crab fauna of Japan, on the other hand, is very well studied over a long period of time (e.g., Utinomi 1944; Takeda and Tamura 1983, 1985; Zayasu et al. 2013). The Ogasawara Islands (also known as the Bonin Islands) are located ca. $1000 \mathrm{~km}$ south of Tokyo and consist of oceanic islands that have never been connected to continental landmasses. The crustacean fauna of these islands is fairly well known, and a total of 250 species belonging to 41 families have been recorded from the islands (Komatsu 2011). Five gall crab species have so far been recorded from the Ogasawara Islands, namely Cryptochirus coralliodytes Heller, 1861, Dacryomaia japonica (Takeda and Tamura, 1981), Lithoscaptus tri (Fize and Serène, 1956), Opecarcinus crescentus (Edmondson, 1925) and the recently 


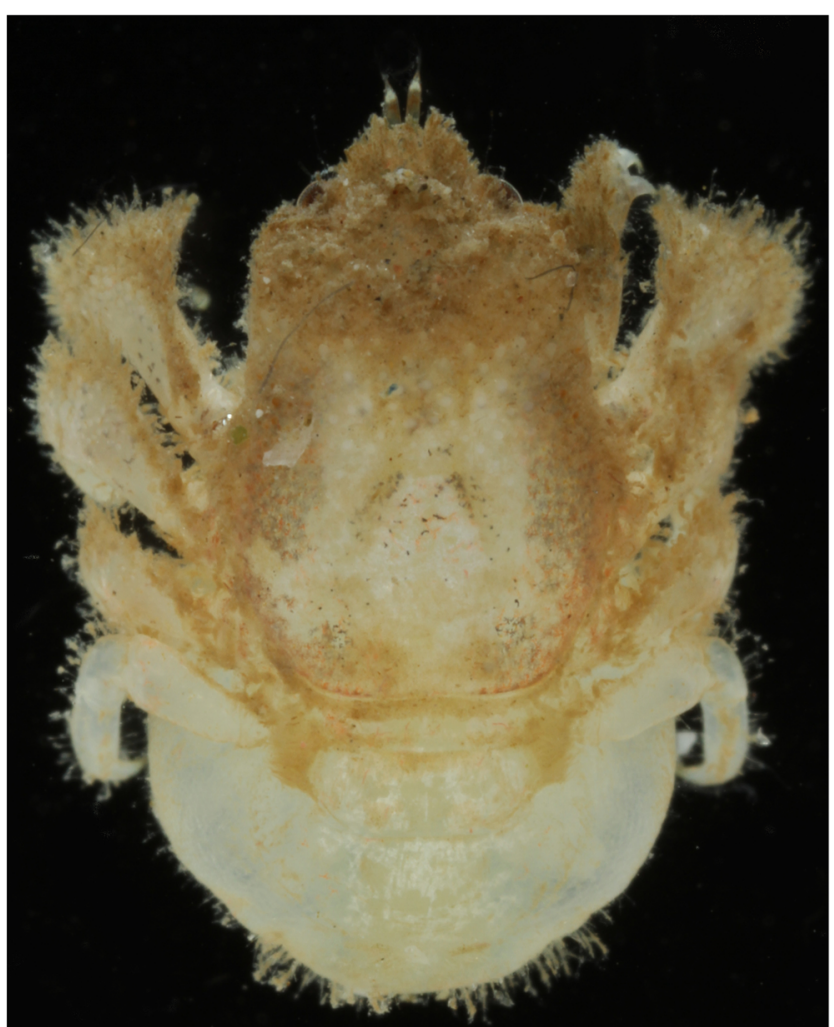

Fig. 1 Female Opecarcinus cathyae collected from $12 \mathrm{~m}$ depth in Iguma Bay, Haha-Jima, Ogasawara Islands (Japan) from the scleractinian coral Pavona clavus

described Fizesereneia daidai Zayasu, 2013 (Komatsu 2011; Zayasu et al. 2013).

\section{Materials and methods}

Diversity surveys were carried out in the Red Sea (March 2013) and around Magoodhoo Island, Faafu Atoll, Maldives (May 2014; February 2015). In addition, specimens collected from the Ogasawara Islands (February 2016) became available. Scleractinian corals were searched for gall crabs using SCUBA diving to approx. $30 \mathrm{~m}$ depth. Gall crabs were removed from the corals and photographed in the laboratory with a digital SLR camera equipped with a macro-lens, and subsequently preserved in $80 \%$ ethanol. Crab specimens are deposited in the Crustacea collection of Naturalis Biodiversity Center in Leiden, The Netherlands (formerly Rijksmuseum van Natuurlijke Historie, collection coded as RMNH.Crus.D), and the Ryukyu University Museum, Fujukan (RUMF), University of the Ryukyus, Okinawa, Japan. The newly obtained material from the Red Sea, Maldives and Japan, as well as the Indonesian and Malaysian material examined in Van der Meij (2014), was sequenced (COI mtDNA; Folmer et al. 1994) following the protocol in Van der Meij (2015b). The sequences are deposited in GenBank under the accession numbers KM396420 and KY013332-KY013342.

\section{Results and discussion}

Cryptochiridae Paul'son, 1875

Opecarcinus Kropp and Manning, 1987

Opecarcinus cathyae van der Meij, 2014

(Fig. 1)

Material examined. Naturalis Biodiversity Center: Red Sea. RMNH.Crus.D.54355, W Shib Nazar, off Thuwal, Saudi Arabia $\left(22^{\circ} 19^{\prime} 36.5^{\prime \prime} \mathrm{N}, 38^{\circ} 51^{\prime} 08.8^{\prime \prime} \mathrm{E}\right), 16$ March 2013, 2 ovigerous females, 1 male, leg. F Benzoni. Maldives. RMNH.Crus.D.57227, Sunny Reef, Maghoodhoo, Faafu Atoll $\left(03^{\circ} 08^{\prime} 40.7^{\prime \prime} \mathrm{N}, 73^{\circ} 00^{\prime} 45.6^{\prime \prime} \mathrm{E}\right), 15 \mathrm{~m}$ depth, 19 February 2015, 2 ovigerous females, 3 males, leg. SET van der Meij. RMNH.Crus.D.57228, Maghoodhoo, Faafu Atoll, 14 May 2014, 2 males, leg. F Benzoni. Ryukyu University Museum, Fujukan: Japan. RUMF-ZC-4318, Iguma Bay, Haha-Jima, Ogasawara Isls, $12 \mathrm{~m}$ depth, 20 February 2016, 1 ovigerous female, leg. H Tachikawa. All specimens were collected from Pavona clavus (Dana, 1846).

Type locality. Creach Reef, Semporna district, Sabah, Malaysia $\left(04^{\circ} 18^{\prime} 58.8^{\prime \prime} \mathrm{N}, 118^{\circ} 36^{\prime} 17.3^{\prime \prime} \mathrm{E}\right)$.

Diagnosis. See Van der Meij (2014) for a full description of this species.
Fig. 2 Distribution records of Opecarcinus cathyae based on Van der Meij (2014) and the new records from the Red Sea, Maldives and Japan (diamonds). The type locality (Creach Reef, Semporna, Malaysia) is indicated with a star

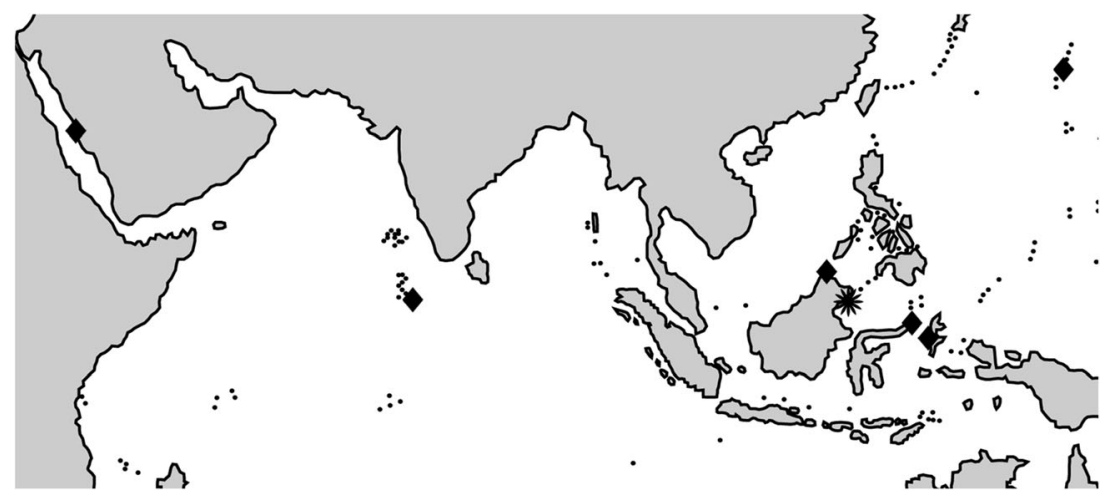


Remarks. The species can locally occur in high densities in large $P$. clavus colonies, with up to 200 individuals per $\mathrm{m}^{-2}$ (Hoeksema and Van der Meij 2013). Opecarcinus cathyae is a uniform species; all specimens from the various, distant localities are in agreement with the original description. Some minor color variations were noticed, with the specimens from the Red Sea having more of an orange hue than those sampled from the other localities.

COI barcoding. Three haplotypes were encountered in the 12 COI sequences of $O$. cathyae. RMNH.Crus.D.54275 from Kudat (Malaysia) and RMNH.Crus.D.54202 from Lembeh Strait (Indonesia) each have a one base pair difference with the remaining ten sequences. The sequences from the Red Sea, Maldives and Japan are identical to each other.

Distribution records. Previous records of this species include various locations in Indonesia (Lembeh Strait, N Sulawesi; Gura Ici, Halmahera) and Malaysian Borneo (Kudat, N Sabah; Semporna, E Sabah), and a possible record from Fiji. The new records from the Red Sea, Maldives and Japan considerably expand the known distribution range of this species to the east and west (Fig. 2). Opecarcinus cathyae now has one of the widest known recorded distribution ranges for all gall crabs. Wide distribution ranges have been reported for the gall crab species Cryptochirus coralliodytes, Neotroglocarcinus dawydoffi (Fize and Serène, 1956), and Fungicola syzygia van der Meij, 2015 (Takeda and Tamura 1986; van der Meij and Reijnen 2014; van der Meij 2015b). Molecular data for these species confirmed their wide distribution records. However, in the reportedly widespread species Hapalocarcinus marsupialis Stimpson, 1859, cryptic lineages are expected based on molecular data (Castro 2011; van der Meij and Schubart 2014). More distribution records for Cryptochiridae, preferably including molecular data, are needed to better understand their biogeographic patterns.

Acknowledgments We thank Hiroyuki Tachikawa for collecting the Japanese material used in this study. Fieldwork in the Red Sea was supported by the King Abdullah University of Science and Technology under the Biodiversity in the Saudi Arabian Red Sea program (award number CRG-1-BER-002 to MLB). We are grateful to the University of MilanoBicocca Marine Research and High Education (MaRHE) Centre in Magoodhoo, the Ministry of Fisheries and Agriculture, Republic of Maldives and the community of Maghoodhoo, Faafu Atoll, Simone Montano and Davide Seveso (MaRHE), Tokyo Metropolitan Ogasawara Island Branch Office, and to Teturo Sasaki (Institute of Boninology) for their help and dive support during fieldwork in the Maldives and the Ogasawara Islands. The field work of the first author in the Maldives and Japan was supported by a 2015 grant from the Academy Ecology Fund (KNAW), 2015 and 2016 grants from the TREUB-maatschappij (Society for the Advancement of Research in the Tropics), and by the John Fell Oxford University Press Research Fund.
Open Access This article is distributed under the terms of the Creative Commons Attribution 4.0 International License (http:// creativecommons.org/licenses/by/4.0/), which permits unrestricted use, distribution, and reproduction in any medium, provided you give appropriate credit to the original author(s) and the source, provide a link to the Creative Commons license, and indicate if changes were made.

\section{References}

Castro P (2011) Catalog of the anomuran and brachyuran crabs (Crustacea: Decapoda: Anomura, Brachyura) of the Hawaiian Islands. Zootaxa 2947:1-154

Folmer O, Black M, Hoeh W, Lutz R, Vrijenhoek R (1994) DNA primers for amplification of mitochondrial cytochrome c oxidase subunit I from diverse metazoan invertebrates. Mol Mar Biol Biotech 3:294-297

Hoeksema BW, van der Meij SET (2013) Gall crab city: an aggregation of endosymbiotic crabs inhabiting a colossal colony of Pavona clavus. Coral Reefs 32:59

Komatsu H (2011) Crabs dredged off the Ogasawara Islands (Crustacea, Decapoda, Brachyura). Mem Nat Sci Mus (Tokyo) 47:219-277

Kropp RK, Manning RB (1987) The Atlantic gall crabs, family Cryptochiridae (Crustacea: Decapoda: Brachyura) Smithson Contr Zool 462:1-21

Takeda M, Tamura Y (1983) Coral-inhabiting crabs of the family Hapalocarcinidae from Japan. IX. A small collection made at Kushimoto and Koza, the Kii Peninsula. Bull Nat Sci Mus Series A: Zool 9:1-12

Takeda M, Tamura Y (1985) Coral-inhabiting crabs of the family Hapalocarcinidae from Japan X. Collections from Hachijo Island in the Izu Islands. Bull Nat Sci Mus Series A 11:99-108

Takeda M, Tamura Y (1986) Coral-inhabiting crabs of the family Hapalocarcinidae from Japan. XI. Biogeographical distribution. Bull Biogeo Soc Jpn 41:61-70, figs. 1-9

Utinomi H (1944) Studies on the animals inhabiting reef corals. III. A revision of the family Hapalocarcinidae (Brachyura) with some remarks on their morphological peculiarities. Palao Trop Bio Stat Stud 2:687-731

van der Meij SET (2014) A new species of Opecarcinus Kropp \& Manning, 1987 (Crustacea: Brachyura: Cryptochiridae) associated with the stony corals Pavona clavus (Dana, 1846) and P. bipartita Nemenzo, 1980 (Scleractinia: Agariciidae). Zootaxa 3869:44-52

van der Meij SET (2015a) Rediscovery of Fizesereneia tholia Kropp, 1994 (Decapoda: Cryptochiridae). Crustaceana 88:741-745

van der Meij SET (2015b) Host relations and DNA reveal a cryptic gall crab species (Crustacea: Decapoda: Cryptochiridae) associated with mushroom corals (Scleractinia: Fungiidae). Contr Zool 84:39-57

van der Meij SET, Reijnen BT (2014) The curious case of Neotroglocarcinus dawydoffi (Brachyura, Decapoda): biogeographic patterns resulting from isolation. Sys Biodivers 12:503-512

van der Meij SET, Schubart CD (2014) Monophyly and phylogenetic origin of the gall crab family Cryptochiridae (Decapoda: Brachyura). Invert Syst 28:491-500

van der Meij SET, Berumen ML, Paulay G (2015) A new species of Fizesereneia Takeda \& Tamura, 1980 (Crustacea: Brachyura: Cryptochiridae) from the Red Sea and Oman. Zootaxa 3931:585-595

Zayasu Y, Nomura K, Seno K, Asakura A (2013) A new species of Fizesereneia Takeda \& Tamura, 1980 (Crustacea: Decapoda: Brachyura: Cryptochiridae) from Japan. Zootaxa 3681:257-269 